\title{
TWIERDZA PONAD MIASTEM, CZYLI O WPŁYWIE GARNIZONU NA ŻYCIE SREBRNEJ GÓRY W OKRESIE FRYDERYCJAŃSKIM (1775-1807)
}

\section{Tomasz Przerwa}

Uniwersytet Wrocławski

\section{ABSTRACT \\ THE FORTRESS ABOVE THE CITY: INFLUENCE OF THE GARRISON ON LIFE OF THE TOWN OF SREBRNA GÓRA'S IN 1775-1807}

The King of Prussia Frederick II, also known as Frederick the Great, decided to build the fortress Srebrna Góra which came to exert enormous influence on the fate of the Lower Silesian small town located at its feet. A huge fortress and the neighbouring Garrison dominated the declining mining and textile centre, that had both positive and negative repercussions. The article depicts the consequences of the military "promotion" of the town of Srebrna Góra, where civilians lived in a sense in the shade of the Garrison and at the same time benefited much from this situation. There is some peculiarity to the described case, as the local Fortress Garrison significantly outnumbered the local community.

Key words: Prussia, Silesia, Srebrna Góra, garrison, fortress, town.

Słowa kluczowe: Prusy, Śląsk, Srebrna Góra, garnizon, twierdza, miasto.

Decyzja króla Prus Fryderyka II zwanego Wielkim o budowie twierdzy srebrnogórskiej (1764-1785) zaważyła na losach położonego u jej stóp miasteczka dolnośląskiego. Potężna warownia górska i przydany jej w 1775 roku garnizon zdominowały niewielką Srebrną Górę (Silberberg), co skutkowało wieloma następstwami. Zachowane źródła nie pozwalają przedstawić pełnego bilansu korzyści i strat wynikających z przekształcenia tej miejscowości w miasto garnizonowe, zresztą w poszczególnych okresach kształtował się on zapewne różnie. Nie da się tego powiedzieć jedynie 
o tragicznych wydarzeniach roku 1807 , kiedy podczas obrony twierdzy przed wojskami napoleońskimi większa część zabudowy miejskiej uległa zniszczeniu. Srebrna Góra została z czasem odbudowana, ale demilitaryzacja twierdzy w 1860 roku i ostateczna likwidacja miejscowego garnizonu w 1867 roku ponownie zachwiały egzystencją mieszkańców, którzy musieli szukać nowych źródeł utrzymania. Ratunku upatrywano między innymi w obsłudze turystów wabionych legendą ,śląskiego Gibraltaru" ". Odłóżmy jednak na bok wątek późniejszego funkcjonowania warowni i powróćmy do tematu relacji występujących na styku militarnej i cywilnej społeczności miasteczka w okresie największego znaczenia srebrnogórskiego zespołu fortecznego (1775-1807). Jakkolwiek w starszych polskich ujęciach dziejów miejscowości kreślono ten ich fragment w wyraźnie negatywnym świetle, nowsze badania pokazują przecież, że rzeczywistość była dużo bardziej złożona². Więcej faktów przemawia w sumie za ożywieniem gospodarczym i kulturowym oraz ogólnym podniesieniem poziomu cywilizacyjnego Srebrnej Góry aniżeli za jej upadkiem. Ludność cywilna żyła wprawdzie w cieniu twierdzy i miejscowego garnizonu, ale jednocześnie niemało na tym korzystała.

Pytania o wpływ wojska na życie ludności cywilnej mają w przypadku Srebrnej Góry szczególny wymiar, ponieważ miejscowość ta w sferze militarnej aż do połowy XVIII wieku nie odgrywała większej roli. Peryferyjnie położone miasto powstało dopiero w XVI wieku i miało początkowo wybitnie górniczy charakter. Nie zostało też zaopatrzone w fortyfikacje. Wyczerpywanie się wartościowych pokładów rudy srebra i ołowiu, położenie miejscowości w ciasnej dolinie górskiej przy mniej znanej drodze przecinającej Sudety, zmiany właścicieli, a wreszcie zniszczenia dokonane w luterańskim miasteczku przez żołnierzy Albrechta Wallensteina w trakcie wojny trzydziestoletniej (1633 r.) blokowały rozwój tego ośrodka. Sytuację ratował rozkwit sudeckiego włókiennictwa, ale też najbliższa okolica Srebrnej Góry nie stanowiła jego ścisłego centrum. Pod koniec XVIII wieku tkactwo ręczne zaczynało zresztą popadać w strukturalny kryzys, co powodowało spadek znaczenia, a zarazem zaludnienia górskich rejonów Śląska. Postępy dziewiętnastowiecznej industrializacji, urbanizacji i mechanizacji dodatkowo obnażały słabość podupadłych ośrodków górniczych, w konsekwencji traciły one prawa miejskie (jak Bolesławów), względnie zapadały w głęboki letarg (jak Miedzianka). Można w sumie zaryzykować twierdzenie, że w dłuższej perspektywie decyzja Fryderyka II o budowie w sąsiedztwie Przełęczy Srebrnej potężnej twierdzy uchroniła Srebrną Górę przed podobnym losem, a na pewno dała jej zupełnie nową szansę rozwoju. O sygnalizowanej wyjątkowości srebrnogórskiej soczewki decyduje zresztą nie tylko skala militarnej inwestycji i obecności wojska w tym nie dość okazałym ośrodku, ale też sam moment dziejowy. Gwałtowna militaryzacja miasteczka nastąpiła w epoce fryderycjańskiej, kiedy potrzeby armii - podpory monarchii pruskiej - miały pierwszeństwo. Przesunięcie na

1 Więcej nt. twierdzy srebrnogórskiej: G. Podruczny, T. Przerwa, Twierdza Srebrna Góra, Warszawa 2010, ss. 549.

2 Szerzej: T. Przerwa, Życie w cieniu fryderycjańskiej twierdzy: przypadek Srebrnej Góry [w:] Zamki, twierdze i garnizony Opola, Śląska i dawnej Rzeczypospolitej, red. T. Ciesielski, Zabrze 2010, s. $97-108$. 
Śląsk znacznych sił zbrojnych, rozbudowa infrastruktury militarnej i wprowadzenie kantonalnego systemu rekrutacji żołnierzy kontrastowały z nieodległym okresem rządów Habsburgów, tak więc pruskie działania i regulacje mogły być postrzegane w regionie jako radykalne i obce. Przypomnijmy, prowincja śląska została przyłączona do Prus w wyniku pierwszej wojny śląskiej (1740-1742), ale o ten nadzwyczaj cenny nabytek musiał Fryderyk II walczyć z Habsburgami aż do 1763 roku. To właśnie doświadczenia trzech wojen śląskich stały za jego decyzją o budowie koło Srebrnej Góry zupełnie nowej twierdzy. Mieszkańcy miasteczka nie mieli, naturalnie, żadnego wpływu na kreślone wówczas plany i na ich późniejszą realizację.

Nie dysponujemy przekazami źródłowymi, które pozwoliłyby dokładnie prześledzić proces przemiany peryferyjnego miasteczka w ośrodek garnizonowy, ale przynajmniej niektóre następstwa możemy przecież uchwycić. Na początek zwróćmy uwagę na zmiany w zaludnieniu Srebrnej Góry, które powinny oddawać ogólniejsze trendy. Według Friedricha Alberta Zimmermanna, osiemnastowiecznego pisarza i statystyka śląskiego, w 1756 roku - u progu trzeciej wojny śląskiej (1756-1763) miało zamieszkiwać Srebrną Górę 1018 osób, 20 lat później (w schyłkowym okresie budowy twierdzy) - 883, w 1778 roku - 901, w 1779 roku - 943, w 1780 roku - 892, w 1781 roku -874 , a w 1782 roku $-837^{3}$. Z miejscowego zestawienia za 1758 rok wynika, że miasteczko liczyło wówczas 993 mieszkańców ${ }^{4}$, a zatem wojna - zdaje się - początkowo nie przysporzyła mu większych strat. Takowe mogły za to wystąpić w ostatniej fazie konfliktu, kiedy w Srebrnej Górze i jej sąsiedztwie rozlokowały się znaczne siły Habsburgów (1760-1763). Nie dysponujemy jednak danymi demograficznymi z tego okresu. O ile przywołane liczby oddają faktyczne zmiany zaludnienia, miejscowa populacja skurczyła się we wskazanym ćwierćwieczu o blisko $18 \%$. Nie można wykluczyć ewentualności, że głównym powodem była wspomniana wojna, ale nawet $\mathrm{w}$ takim przypadku zaskakuje ograniczony i raczej niestabilny przyrost miejscowej społeczności w okresie budowy twierdzy, dla której to inwestycji miasteczko stanowiło naturalne zaplecze. Zauważmy, że w najlepszych latach - w drugiej połowie lat 60 . czy też na początku lat 70 . XVIII wieku - zatrudniano tam po-

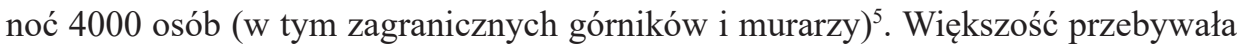
w miejscowości czasowo, lecz niektórzy mogli przecież chcieć związać się z nią na dłużej. W katolickich księgach metrykalnych ze Srebrnej Góry odnotowano małżeństwa zawierane w latach 1767-1768 przez ściągniętych do miasteczka murarzy ${ }^{6}$. Nie natrafiono na materiały, które pozwalałyby poznać organizację pracy tysięcy robotników sprowadzonych do pracy. Ich pobyt musiał niemniej pobudzić miejscową gospodarkę. W połowie lat 70. XVIII wieku zasadnicza część zespołu fortecznego była już gotowa, przedstawione liczby odnoszą się zatem do schyłkowego okresu budowy

3 F.A. Zimmermann, Beyträge zur Beschreibung von Schlesien, Bd. I, Stück 4, Brieg 1783, s. 64.

4 Archiwum Państwowe we Wrocławiu. Oddział w Kamieńcu Ząbkowickim (dalej: AP KZ), Akta miasta Srebrna Góra (dalej: ASG), sygn. 65: Bericht des Syndikus der Stadt Silberberg über die dortige katholische Kapelle und summarisches Verzeichnis der evang. u. kathol. Einwohner, s. 8-9.

5 W. Bley1, Silberberg. Die Passfestung Schlesiens, Breslau 1938, s. 22.

${ }_{6}$ Archiwum Archidiecezjalne we Wrocławiu (dalej: AA Wr), Księgi metrykalne parafii Srebrna Góra, sygn. 481f: Trauungs-Buch der Kirche zu der Catholischen Curatie Silberberg 1766-1817. 
i tym samym nie muszą oddawać wcześniejszego ożywienia. Krótkotrwały wzrost (1778-1779) nakłada się zaś na lata wojny o sukcesję bawarską, kiedy to okolice miasteczka stały się miejscem koncentracji głównych sił pruskich.

Przywołane uprzednio dane nie pozwalają dostrzec dodatniego wpływu wprowadzenia garnizonu do Srebrnej Góry. Nie powinniśmy jednak zapominać, że obsługa wojska nałożyła się na dotychczasową, zdecydowanie inną orientację gospodarczą miasteczka. Jego gwałtowna militaryzacja mogła zatem zachęcać/zmuszać miejscową ludność do zmiany profilu zarobkowania, względnie skutkować jej częściową wymianą. Określoną pojemność zabudowań miejskich przy dużym pozacywilnym popycie na lokale mieszkalne również powinniśmy brać pod uwagę. Należy jednocześnie wspomnieć generalną słabość srebrnogórskiej gospodarki. Cztery doroczne jarmarki nie czyniły z górskiego miasteczka ważnego centrum handlowego, a warzelnie potażu - ośrodka produkcyjnego. Mieszkańcy trudnili się rzemiosłem, ale nie było ono nawet na tyle silne, aby można było powołać miejscowe organizacje cechowe. Rozwój sudeckiego tkactwa nie ominął miasta, stąd w 1787 roku odnotowano w nim 78 krosien. Dodajmy do tego kilku kupców sprzedających tekstylia za granicę. Powojenne ograniczenia $\mathrm{w}$ wymianie handlowej z krajami habsburskimi mogły ciążyć na pomyślności pogranicznego miasta. Wyraźny kryzys w tym względzie dostrzeżono jednak dopiero pod koniec XVIII wieku. Ówcześni srebrnogórzanie przyczyn załamania upatrywali w odcięciu od austriackich rynków zbytu, toczonych w Europie wojnach i śmierci największego miejscowego kupca Gottlieba Adolpha (1793 r.). Jeden ze świadków zauważył przy tym, że byłoby jeszcze gorzej, gdyby nie świadczone usługi ${ }^{7}$, co należy najpewniej wiązać z obsługą garnizonu. W 1783 roku, osiem lat po przybyciu stałego garnizonu, Friedrich A. Zimmermann w opisie źródeł utrzymania srebrnogórzan wymienił na pierwszym miejscu warzenie piwa, czym zajmowało się 62 uprawnionych obywateli. $Z$ handlu żyło 8 kupców tekstylnych i 7 drobniejszych kramarzy. $Z$ pozostałych profesji nadal najliczniej reprezentowane były zawody związane $\mathrm{z}$ włókiennictwem: 30 tkaczy (płócienników?), 7 sukienników, 3 postrzygaczy sukna, 5 farbiarzy i 2 wytwórców krosien. W kilkusetosobowym miasteczku pracowało poza tym: 9 rzeźników, 7 piekarzy, piernikarz i browarnik, 9 krawców, dziewiarz, pończosznik, rękawicznik, 10 szewców, 4 kuśnierzy, po 2 białoskórników i kurdybaników, 5 rymarzy, bednarz i powroźnik, 6 stolarzy, po 2 tokarzy i ślusarzy, kowal, po 2 murarzy i szklarzy, 3 mydlarzy, 2 golibrodów, łaziebnik, zegarmistrz, kominiarz, 2 wytwórców potażu i 1 - talerzy ${ }^{8}$. Brakuje przesłanek do przypisania niektórych specjalności wyłącznie obsłudze wojskowych, ale też bez uwzględnienia potrzeb żołnierzy i bardziej wyrafinowanych życzeń kadry oficerskiej samo występowanie, względnie tak liczna reprezentacja przynajmniej części wymienionych specjalności w niewielkim i pozbawionym szerszego oddziaływania ośrodku wydawałaby się niezwykła.

M. Frisch, Im Namen der Allerheiligsten und Hochgelobten Dreieinigkeit, Silberberg 1795, kopia rękopisu w zbiorach Autora.

8 F.A. Zimmermann, op. cit., s. 66. 


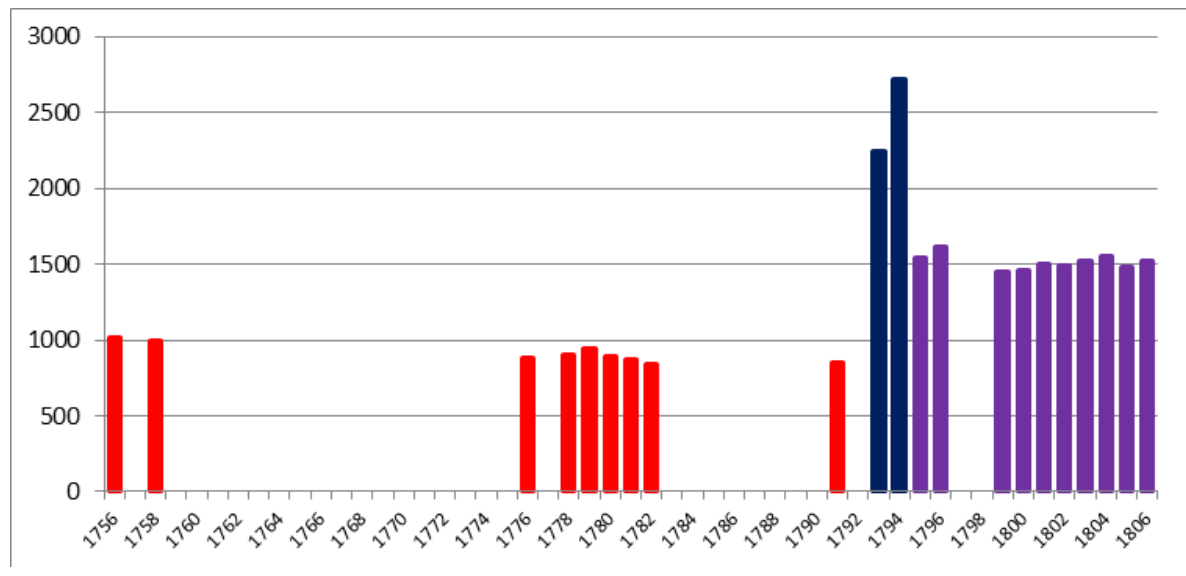

Wykres 1. Zaludnienie Srebrnej Góry w latach 1756-1806

Źródło: opracowanie własne na podstawie: F.A. Zimmermann, Beyträge zur Beschreibung von Schlesien, Bd. I, Stück 4, Brieg 1783, s. 64; „Schlesische Provinzialblätter”, Bd. XIX (1794) - Bd. XLIV (1806).

Wróćmy jednak do tematu zmian w zaludnieniu Srebrnej Góry, które możemy ponownie śledzić dzięki zestawieniom publikowanym na przełomie XVIII i XIX wieku w poważnym wrocławskim periodyku „Schlesische Provinzialblätter”. Zgodnie z nimi w 1793 roku Srebrną Górę miało zamieszkiwać 2248 osób, w 1794 roku - 2719, w 1795 roku - 1544, w 1796 roku - 1618, w 1799 roku - 1447, w 1800 roku - 1463, w 1801 roku - 1498, w 1802 roku-1492, w 1803 roku - 1528, w 1804 roku -1555 , w 1805 roku - 1480, a w 1806 roku - 15199. Nawet przy założeniu niedoskonałości ówczesnej statystyki nagły, dwu- bądź trzykrotny przyrost populacji miasteczka między latami 80. i 90. XVIII wieku wydaje się mało prawdopodobny. Wątpliwości rodzą też gwałtowne wahnięcia z lat 1793-1795 i późniejsze ustabilizowanie zaludnienia na poziomie 1500 osób. Ponieważ inne źródła nie sygnalizują takich wzrostów, a dekadę wcześniej występowała nawet tendencja spadkowa,

9 Menschenzahl in Schlesien und der Grafschaft Glatz im Jahre 1793, „Schlesische Provinzialblätter” (dalej: „SPB”) 1794, Bd. XIX, s. 432; Menschenzahl im Preussischen Schlesien und in der Grafschaft Glatz im Jahr 1794, „SPB” 1795, Bd. XXI, s. 232; Verzeichniß der im Preußl. Schlesien und in der Grafschaft Glaz, ohne das würkliche Militair gezählten Menschen in den Jahren 1795 u. 1796, „SPB” 1796, Bd. XXIV, s. 281; Menschenzahl in Schlesien im Jahr 1799, „SPB” 1799, Bd. XXX, s. 341; Menschenzahl in Schlesien im Jahre 1800, „SPB” 1800, Bd. XXXII, s. 262; Menschenzahl in Schlesien im Jahr 1801, „SPB” 1801, Bd. XXXIV, s. 269; Verzeichniß der Menschenzahl im Preußl. Schlesien und in der Grafschaft Glatz im Jahr 1802, „SPB” 1802, Bd. XXXVI, s. 337; Tabelle von der Menschenzahl im Jahre 1803, „SPB” 1803, Bd. XXXVIII, s. 250; Tabelle von der Menschenzahl in Schlesien im Jahr 1804, ,SPB” 1804, Bd. XL, s. 252; Tabelle [von der Menschenzahl in Schlesien im Jahr 1805], „SPB” 1805, Bd. XLII, s. 263; Tabelle von der Menschenzahl in Schlesien für das J. 1806, „SPB” 1806, Bd. XLIV, s. 336. 
pozostaje powiązać owe różnice ze zmianą systemu liczenia. Srebrna Góra nie miała przedmieść i zależnych od niej majątków, dlatego należy założyć zmianę kryteriów, tj. dodanie pomijanej dotychczas grupy ludności. We wcześniejszych przypadkach niemal na pewno nie uwzględniano żołnierzy i towarzyszących im rodzin, których członkowie wchodzili w skład osobnego stanu żołnierskiego. Tych pierwszych naliczono w 1787 roku $1225^{10}$, co odpowiada sile stacjonujących w miasteczku oddziałów. Poza ewentualnym wyjątkiem lat 1793-1794 garnizon nie był uwzględniany w srebrnogórskich statystykach okresu fryderycjańskiego. Przy założeniu, że liczba cywilów sięgała w tym czasie najwyżej 900, występującą różnicę - rzędu 600 mieszkańców - wypadałoby zatem przypisać stanowi żołnierskiemu. Wspomniane różnice można wyjaśnić, o ile się przyjmie, że w 1793 roku zsumowano liczbę cywilnych mieszkańców i żołnierzy (bez rodzin?), w 1794 roku mieszkańców, żołnierzy i członków ich rodzin, a w kolejnych latach jedynie mieszkańców i członków rodzin żołnierskich (bez żołnierzy) ${ }^{11}$. Na zakończenie tych ogólnych szacunków należy jeszcze zauważyć, że przynajmniej niektórzy obywatele miasta, co znajduje potwierdzenie w źródłach, należeli do stanu żołnierskiego. Utrudnia to precyzyjne rozdzielenie obu grup, a zarazem pokazuje przenikanie żołnierzy i ich rodzin do społeczności Srebrnej Góry.

Skierowany do miasteczka garnizon przewyższał liczebnie zamieszkałą tam społeczność, a żołnierzom - jak wspomnieliśmy - towarzyszyły rodziny podlegające wojskowej jurysdykcji. Niewątpliwie była to znacząca grupa nowych mieszkańców, o czym przekonuje analiza katolickich ksiąg metrykalnych. Właściwie od czasu pojawienia się w Srebrnej Górze stałego garnizonu (1775 r.) do katastrofalnej dla Prus wojny (1806-1807) liczba żołnierskich ślubów, chrztów i pochówków w Srebrnej Górze przewyższała liczbę sakramentów udzielanych cywilom. W latach 1776-1795, kiedy w miasteczku stacjonował regiment piechoty numer 50 (w sile wzmocnionego batalionu), zawarto 82 śluby żołnierskie i 41 cywilnych, w latach 1796-1807, kiedy trzon garnizonu tworzyły tak zwane trzecie bataliony regimentów piechoty numer 33 i 47, ślubów było odpowiednio 93 i 37. Wzrost liczby małżeństw zawieranych przez żołnierzy (w skali roku średnio 4,1 dla regimentu nr 50 i 9,3 dla regimentów nr 33 i 47) można tłumaczyć wzrostem ogólnego udziału katolików w garnizonie. Regiment numer 50 tworzyli zresztą w większym stopniu wysłużeni żołnierze, co musiało się przekładać na ich stan cywilny. Oddział ów sformowano w latach 1773-1775 w nieodległym Dzierżoniowie i już tam - jak wspomina miejscowa kronika - wojskowym towarzyszyła chmara kobiet i dzieci ${ }^{12}$. Trzecie bataliony były zaś $\mathrm{w}$ większym stopniu uzupełniane młodszymi kantonistami. Wymiana garnizonu rzutowała zapewne również na liczbę narodzin. W latach 1776-1795 ochrzczono w Srebrnej Górze 357 wojskowych oraz 305 cywilnych dzieci katolików, w kolejnej dekadzie -

10 Generalne tabele statystyczne Śląska 1787 roku, oprac. T. Ładogórski, Wrocław 1954, s. 106.

11 Powyższą rekonstrukcję uprawdopodabnia relacja z połowy lat 90 . XVIII w., wedle której miasteczko zamieszkiwało wówczas 2248 osób, co pokrywa się z danymi za 1793 r. Dwa lata wcześniej tamtejsza społeczność liczyła 2520 mieszkańców, a bez żołnierzy (i zapewne rodzin żołnierskich) - około 850. Ch. Weiss, Wanderungen in Sachsen Schlesien Glatz und Böhmen, T1. 2, Leipzig 1797, s. 38.

12 E. Hasse, Chronik der Stadt Reichenbach im Eulengebirge, Reichenbach 1929, s. 116. 
odpowiednio 258 i $176^{13}$. Katolicy stanowili mniejszość w mieście (luteranie przeważali nad nimi przynajmniej dwukrotnie) $)^{14}$, a zapewne również w garnizonie. Przywołane uprzednio wielkości w przypadku całej społeczności należałoby zatem pomnożyć przynajmniej dwukrotnie.

Przesunięcie do małego miasteczka sporego garnizonu (z rodzinami) stwarzało poważne problemy kwaterunkowe. Wystarczy przypomnieć wcześniejsze szacunki, z których wynika, że miasteczko liczące jakieś 900 mieszkańców musiało przyjąć około 1200 żołnierzy i dodatkowo kilkaset osób stanu żołnierskiego. Nie ulega wątpliwości, że wojskowi musieli zdominować Srebrną Górę pod właściwie każdym względem. Zajmowali oni w monarchii pruskiej szczególną pozycję, ale w pozostałych ośrodkach fortecznych i garnizonowych regionu starano się dopasować ich obecność do lokalnych warunków. W omawianym przypadku nadrzędna okazała się idea zabezpieczenia upatrzonego przejścia górskiego, dla którego miasteczko stanowiło niejako korzystny dodatek. Pozostałe twierdze pruskie na Śląsku (może z wyjątkiem Koźla) związane były ze znaczniejszymi ośrodkami miejskimi (w wymiarze administracyjnym, przestrzennym, komunikacyjnym, handlowym i produkcyjnym): Wrocławiem, Głogowem, Brzegiem, Nysą, Świdnicą czy Kłodzkiem ${ }^{15}$, co ułatwiało funkcjonowanie wprowadzonych tam garnizonów. Peryferyjna Srebrna Góra nie była nawet $\mathrm{w}$ stanie pomieścić całej załogi przewidzianej do obrony nowego zespołu fortecznego. Wraz z warownią należało zatem wybudować koszary. Oddano je do użytku w 1776 roku, na tle innych ośrodków śląskich relatywnie wcześnie. Mogło w nich zamieszkać 800 osób. Chodziło głównie o żołnierzy obciążonych rodzinami, zatem problematycznych przy kwaterunku w mieszczańskich domach, oraz skłonny do dezercji element żołnierski. Zauważmy na marginesie, że uciążliwość służby w górskiej okolicy miała - zdaniem jednego z komentatorów - podwyższać liczbę dezercji ${ }^{16}$. Srebrnej Góry nie otaczały mury miejskie, dlatego obwód koszar zamknięty palisadą i wartowniami stanowił w sumie jedyne realne zabezpieczenie przed ucieczką z garnizonu. Tłumaczy to uwagę jednego z podróżników, który wspomniał o jakichś ograniczeniach w udzielaniu żołnierzom pozwoleń na zejście do miasta ${ }^{17}$. Wyjątkowa lokalizacja srebrnogórskich koszar, odsuniętych od miasta, a za-

13 AA Wr, sygn. 481f; sygn. 481a: Tauf-Buch der Kirche zu Silberberg 1766-1785; sygn. 481b: Tauf-Buch der Kirche zu Silberberg 1785-1811.

14 Szerzej o samym miasteczku: J. Dębicki, Pod straża gór - pod straża twierdzy. Srebrna Góra u zbiegu epok: habsburskiej i fryderycjańskiej [w:] Twierdza srebrnogórska, II: Wojna 1806-1807-miasteczko, red. T. Przerwa, G. Podruczny, Wrocław 2008, s. 9-18; idem, Srebrna Góra w czasie konfesjonalizacji [w:] Twierdza srebrnogórska, III: Miasteczko i fortyfikacje, red. T. Przerwa, G. Podruczny, Wrocław 2010, s. 20-32.

15 Z zestawienia opublikowanego w „Schlesische Provinzialblätter” wynika, że w 1800 r. we Wrocławiu mieszkało 59391 osób, w Głogowie - 8985, w Brzegu - 8229, w Świdnicy - 7879, w Nysie 7200 , w Kłodzku - 6608, a w Koźlu - 2108. Poza ostatnim ośrodkiem były to niewątpliwie największe miasta prowincji. Próg 6000 mieszkańców przekroczyły jeszcze tylko: Zielona Góra, Jelenia Góra i Legnica. Menschenzahl in Schlesien im Jahre 1800..., s. 261-263.

16 J.G. Schummel, Reise durch Schlesien im Julius und August 1791, Breslau 1792, s. 292.

17 J.W. Fischer, Bemerkungen auf einer Reise durch einen Theil des Schlesischen Gebirges und der Grafschaft Glaz, Breslau 1793, s. 61-62. 
razem twierdzy, warunkowana była ukształtowaniem terenu i potrzebami obronnymi, a jednocześnie brakiem przestrzeni do ustawienia rozbudowanego zespołu koszarowego w obrębie ciasnej zabudowy miejskiej. Usytuowanie ich przy przełęczy pozwalało dodatkowo kontrolować ruch towarów, co wykorzystywano przy poborze podatków, o czym dowiadujemy się dopiero z dokumentów sporządzonych w $1811 \mathrm{roku}^{18}$.

Pozostali żołnierze (w tym kompania artylerii), oficerowie i urzędnicy forteczni musieli szukać kwater w miasteczku, co wiązało się dla mieszkańców z określonymi niewygodami, ale też korzyściami. Obowiązkowi kwaterunku towarzyszył wszak system finansowych rekompensat, na które zbierano w pruskich miastach specjalny podatek (servis). Niektórzy wojskowi zdołali nadto pozyskać nieruchomości na własność. W 1795 roku należało do nich 15 z blisko 200 budynków. Wśród posesjonatów domów zniszczonych w 1807 roku wymieniono kilku oficerów i urzędników oraz kilku prostych żołnierzy. Ci ostatni zamieszkiwali przeważnie ubogi kwartał Nowego Miasta (Neustadt) ${ }^{19}$. Nieokreślona grupa oficerów, a zapewne również żołnierzy, miała mieszkać w Górnym Budzowie (Oberschönwalde)20, którego rozrzucona wzdłuż drogi przełęczowej zabudowa sąsiadowała bezpośrednio z koszarami i samą twierdzą. Grafika Friedricha Bernharda Wernera z połowy XVIII wieku, czyli jeszcze sprzed budowy twierdzy, pokazuje miasteczko zasadniczo drewniane. Kolejne jego ujęcia i dokładniejsze opisy powstały dopiero w XIX wieku, po gruntownej odbudowie ze zniszczeń wojennych roku 1807 . Nie jesteśmy więc w stanie określić tempa i skali modernizacji miejskiej zabudowy w okresie fryderycjańskim. Takowa niemniej postępowała. Wystarczy wspomnieć o okazałej komendanturze, którą urządzono przy głównym trakcie miejskim w zakupionym w 1794 roku budynku²1 ${ }^{21}$. Część kamiennych portali bramnych w Srebrnej Górze datowana jest zresztą właśnie na koniec XVIII wieku, co uprawdopodabnia powolną przebudowę miasteczka. W 1787 roku dachówka kryła wprawdzie tylko dziewięć budynków srebrnogórskich ${ }^{22}$, ale należy pamiętać, że w miastach śląskich zaczęła się ona upowszechniać w miejsce gontu dopiero za Fryderyka II.

Odwołajmy się do obserwacji poczynionych przez uczonych podróżnych, których wabiła niezwykłość srebrnogórskiej twierdzy ${ }^{23}$. W pozostawionych przez nich relacjach znajdujemy wzmiankę, że z ogromnych środków wydanych na budowę warowni większość pozostała jakoby na miejscu, a to zapewne w postaci zysków mieszkańców. Mieli oni bardzo skorzystać na inwestycji, co poświadczały odnowione i nowo

18 Geheimes Staatsarchiv, Stiftung Preußischer Kulturbesitz (dalej: GStA PK), I HA, Rep. 77, tit. 1296, Nr. 5: Instandsetzung der Pallisades von Silberberg 1811-1812.

19 GStA PK, I HA, Rep. 151, Nr. 11575: Die Unterstützung für die durch die Belagerungen der schlesischen Festungen verunglückten Unterthanen bei Silberberg, Glatz, Cosel, k. 47-53.

20 J.W. Fischer, op. cit., s. 61.

${ }_{21}$ M. Frisch, op. cit.; AP KZ, ASG, sygn. 32: Die zu Silberberg zur Wohnung für den dortigen Kommandanten erkaufte Adolphschne Hauses 1794-1795.

22 GStA PK, I HA, Rep. 151, Nr. 11582: Unterstützungen für die durch Belagerungen der schlesischen Festungen verunglückten Unterthamen bei Silberberg, Glatz, Cosel 1812; Rep. 89, Nr. 30446: Das Retablissement von Cosel und Silberberg 1813/19; Generalne tabele..., s. 203.

${ }_{23}$ T. Przerwa, Twierdza srebrnogórska oczami podróżników (1763-1867) [w:] Twierdza srebrnogórska, red. T. Przerwa, G. Podruczny, Srebrna Góra 2006, s. 89-92. 
zbudowane domy. Ludzie pióra wspominali nadto, że biedne miasto ożyło po okresie marazmu, ponieważ w obsłudze miejscowego garnizonu srebrnogórzanie znaleźli solidne podstawy utrzymania. W latach 80 . XVIII wieku żołnierze mieli powiększać lokalne obroty o 40000 talarów rocznie! Liczba piekarzy, rzeźników, piwowarów i kramarzy zwiększyła się ponoć czterokrotnie. Zyskiwali także inni wytwórcy. Z obsługi garnizonu w sumie utrzymywało się ponad 50 rodzin. W niewielkim miasteczku działało osiem wyszynków $\mathrm{i}$ - jak podkreślano w jednej z relacji - żaden z nich nie bankrutował. Zdaniem elitarnych podróżnych poziom tych lokali pozostawiał wiele do życzenia, ale najwyraźniej zaspakajał oczekiwania żołnierzy. Obecność garnizonu zwiększyła również popyt na żywność, co zaowocowało w 1793 roku wyznaczeniem cotygodniowych targów; dla wygody mieszkańców, ale przede wszystkim garnizo$\mathrm{nu}^{24}$. O podniesieniu ogólnego poziomu życia w miasteczku świadczą otworzona w 1767 roku królewska apteka ${ }^{25}$ oraz uruchomienie stałego połączenia pocztowego. Początkowo obsługiwał je pieszy goniec, a od 1896 roku konny pojazd pocztowy ${ }^{26}$.

Czytelnym przykładem korzystnego wpływu obecności wojska na funkcjonowanie Srebrnej Góry jest rozświetlenie jej ulic latarniami olejowymi w 1799 roku. Z inicjatywą wystąpił - co istotne - komendant twierdzy Johann Adam von Schlemmer, który chciał w ten sposób zapobiec nieszczęśliwym wypadkom, do jakich mogło dochodzić na ulicach pogrążonych $\mathrm{w}$ ciemnościach ${ }^{27}$. Żołnierze pomagali również $\mathrm{w}$ realizacji innych projektów modernizacyjnych, przy czym konkretne dane zachowały się jedynie ze zbiórki na rzecz renowacji wieży kościoła ewangelickiego w 1795 roku. Na liście darczyńców oficerowie miejscowego garnizonu znaleźli się na zaszczytnym pierwszym miejscu, przekazali zresztą zdecydowanie najwyższe kwoty ${ }^{28}$. Uzasadnione wydaje się twierdzenie, że oficerowie miejscowego garnizonu i urzędnicy komendantury tworzyli wówczas lokalną elitę. Przybywali z różnych stron, często z innych rejonów Europy. Szczególnie wielu obcokrajowców służyło w regimencie numer 50, którego kadry licznie zasilili francuskojęzyczni Sabaudczycy z obszaru obecnej Szwajcarii. $\mathrm{Z}$ tego górskiego regionu, co trudno uznać za zbieg okoliczności w przypadku pierwszego pruskiego garnizonu (srebrno)górskiego, pochodzili dowódca wspomnianego regimentu i pierwszy komendant twierdzy Franz Ludwig de la Rossiere vel Francois Louis de Rosiére oraz wielu oficerów, którzy - w opinii jednego z obserwatorów - wyróżniali się towarzyską ogładą i talentem muzycznym. W tym kontekście wspominano o grze na flecie, wiolonczeli i skrzypcach ${ }^{29}$. W relacjach podróżnych, co

24 Biblioteka Śląska w Katowicach (dalej: BŚ), Oddział Zbiorów Specjalnych, sygn. R 1688 III/1: Besondere Nachricht der freyen Bergstadt Silberberg, k. 7; F.A. Zimmermann, op. cit., s. 287; Ch. Weiss, op. cit., s. 38-39; J.A.V. Weigel, Geographische, naturhistorische und technologische Beschreibung des souverainen Herzogthums Schlesien, Tl. 3, Berlin 1801, s. 194; Auszüge aus den Akten (Tagebuch) der Stadtverwaltung Silberberg im Eulengebirge 1790-1811, Hrsg. H. Felkel, U. Felkel, Hamburg 1999, s. 10.

25 W. Brachmann, Beiträge zur Apothekengeschichte Schlesiens, Würzburg 1966, s. 180.

26 F.A. Zimmermann, op. cit., s. 69; Allerley, „SPB” 1796, Bd. XXIV, s. 535.

27 AP KZ, ASG, sygn. 8: Einrichtung des Laternen Wesens zu Silberberg 1799-1807; BŚ, sygn. R 1688 III/2: C.G. Poh1, Chronick von Silberberg zur Fortsatzung der Geschichte von 1795, k. 3v.

28 G. Ernst, Designation, Silberberg 1795, kopia rękopisu w zbiorach Autora.

29 J.G. Schummel, op. cit., s. 282-283. 
znamienne, właściwie pomijano cywilów. Zainteresowania Fryderyka II zapewne nie odbiegały od tego schematu. Inwestycja militarna zmuszała władcę do częstych wizyt w Srebrnej Górze ${ }^{30}$, ale zajęty poważniejszymi sprawami wcale nie musiał się skupiać na jej problemach. Przejazdy królewskie dodawały miastu prestiżu, nadto stanowiły później element lokalnej tożsamości. Świadczą o tym między innymi utrwalone w miejscowym piśmiennictwie opowiastki związane z osobą monarchy. Jedna z nich dotyczy burmistrza Georga Wilhelma Ruhma, którego wojskowi decydenci mieli przedstawić Fryderykowi II jako pijaka. Słowne nieporozumienie uchroniło go jednak przed królewskim gniewem ${ }^{31}$.

Szczególny status armii we fryderycjańskich Prusach stawiał wojskowych w pozycji uprzywilejowanej, co mogło sprzyjać nadużyciom. Z takim przypadkiem mamy najpewniej do czynienia w Srebrnej Górze w 1780 roku. Komendant twierdzy Dietrich de Haas - chorujący na podagrę - źle ponoć znosił hałas uliczny, dlatego rozkazał żołnierzom zablokować drogę biegnącą w pobliżu jego mieszkania. Postawiona straż miała użyć broni, gdyby ktoś chciał przekroczyć zaporę ze ściętego w tym celu drzewa. Sprawę znamy ze skargi oficera miejscowego garnizonu pułkownika Georga von Steensena, który - co godne podkreślenia - jako jedyny uznał owe działania, motywowane prywatnym interesem, za naruszenie porządku publicznego. Z zachowanych akt wynika, że urzędnicy wyjaśniający sprawę uznali ją za pochodną napięć narosłych między komendantem i garnizonem ${ }^{32}$. O ile Steensen nie przesadzał, decyzją Haasa wstrzymano ruch na głównej drodze miasteczka, a mieszkańcy nie zgłaszali zastrzeżeń. Dwadzieścia lat później to jednak magistrat zdecydował się prosić władze zwierzchnie o interwencję. Wspominany już komendant Schlemmer miał w ich odczuciu naruszać kompetencje organów cywilnych. Sprawę badał radca podatkowy Berger z Brzegu, który stanął po stronie mieszkańców. Stwierdził, że komendant błędnie rozumie przysługujące mu prawo współnadzoru i narzuca swą wolę. Wątpliwości budziły dwie jego decyzje. Pierwsza dotyczyła Josephy Birnbaum - Schlemmer nakazał tej kobiecie zamknąć wyszynk. W drugim przypadku miał narzucać piekarzowi zaopatrywanie się w mąkę w urzędzie prowiantowym. Komendant uznał skargę, co znamienne, za przejaw impertynencji! Sprawę piekarza tłumaczył nieporozumieniem, inna procedura obowiązywała bowiem w zakresie wypieków dla wojska, a inna dla mieszkańców. Przypadek Birnbaum - żony podoficera miejscowego garnizonu - okazał się zaś niejednoznaczny, ponieważ jako osoba stanu żołnierskiego, a zarazem mieszczka srebrnogórska podlegała podwójnej jurysdykcji. Komendant tłumaczył nadto, że nie mógł się godzić na lekceważenie przez nią lokalnych przepisów. W wyszynku Birnbaum goście mieli się bowiem bawić długo po

30 K.H.S. Rödenbeck, Tagebuch oder Geschichtskalender aus Friedrich's des Großen Regentenleben (1740-1786), Bd. 2, Berlin 1841, s. 292, 707; Bd. 3, Berlin 1842, s. 22, 186, 196, 197, 266, 332; E. Pfeiffer, Die Revuereisen Friedrichs des Grossen, Berlin 1904, s. 54, 58.

${ }_{31}$ A. Bartscht, Aus Silberbergs friedericianischer Epoche [w:] Festschrift der Hundertjahr-Feier zur Erinnerung an die standhafte Verteidigung Silberbergs, Silberberg 1907, s. 14.

32 AP KZ, ASG, sygn. 31: Die über den Commandanten zu Silberberg Major de Haas beygebrachte Beschwerde wegen unterbrochener öffentlicher Passage durch die Stadt 1780. 
22.00 , od której to godziny obowiązywała cisza nocna ${ }^{33}$. Schlemmer został zapewne oczyszczony z oskarżeń, ponieważ rozgraniczenie kompetencji władz cywilnych i wojskowych nastręczało trudności nie tylko w Srebrnej Górze. Sam magistrat był zresztą zobowiązany instrukcją z 1792 roku do utrzymania harmonii w stosunkach z wojskiem, co przynajmniej częściowo wiązało mu ręce. Wróćmy jednak do osoby Schlemmera. Miał on - wedle relacji Bergera - nakłaniać szewca Thomasa do bezpłatnego reperowania butów i groził mu na wypadek niedostatecznej czołobitności. Oficer obszedł się zresztą nieprzyjemnie z samym radcą podatkowym. Nakazał budzić Bergera rankiem, po czym zarzucił mu, że ten przybył do miasteczka bez zapowiedzi i nie stawił się przed nim. Szczątkowo zachowane akta miejskie nie pozwalają stwierdzić, jak często w Srebrnej Górze dochodziło do podobnych incydentów lub napięć. Nie można ich wykluczyć, ale nie musi to przecież oznaczać, że życie w miasteczku było dla cywilnej ludności pasmem samych udręk.

Przywołane zatargi starano się wyjaśnić. Możemy je uznać za niemiłe, ale nie miały one dramatycznego przebiegu. Analiza ksiąg metrykalnych zdaje się jednocześnie świadczyć, że mieszkańcy miasta i żołnierze miejscowego garnizonu nie pozostawali sobie obojętni. Musiało dochodzić między nimi do częstych kontaktów, skoro zawierano „mieszane” małżeństwa i wybierano na świadków przedstawicieli drugiego stanu $^{34}$. Powyższe praktyki nie oznaczają zapewne pełnego przenikania się obu społeczności. Jedynie w przypadku 9,7\% małżeństw zawartych w miejscowym kościele katolickim w latach 1775-1807 wybranka żołnierza pochodziła ze Srebrnej Góry, do czego możemy doliczyć partnerki zamieszkałe w sąsiednich wioskach (10,7\%). Oznacza to, że zdecydowaną większość małżeństw wojskowi zawarli bez wyraźnego związku z obecnym miejscem stacjonowania. Warto zaznaczyć, że 30\% małżeństw zawarto w obrębie stanu żołnierskiego. Do ślubów córek żołnierzy miejscowego garnizonu z okolicznymi mężczyznami dochodziło jeszcze rzadziej. To ostatnie thumaczy z pewnością niska pozycja społeczna i materialna rodzin prostych żołnierzy. O panujących w tej grupie warunkach życia wiele mówi wysoka - wyższa niż w przypadku ludności cywilnej - śmiertelność dzieci i częste wypadki gruźlicy ${ }^{35}$. Tylko część żołnierzy decydowała się na małżeństwo, co rodzi pytania o nieformalne kontakty seksualne, w tym o prostytucję. Jedynego potwierdzenia sygnalizowanych zjawisk możemy się dopatrywać we wzroście liczby chrztów dzieci nieślubnych. W badanym okresie (1775-1807) ochrzczono w miejscowym kościele katolickim 68 nieślubnych dzieci (14,6\% chrztów cywilnych). Tylko w dwóch przypadkach przypisano ojcostwo żołnierzom miejscowego garnizonu (majorowi i muszkieterowi). Takie adnotacje pojawiały się w księgach niezwykle rzadko, ale podobnych powiązań mogło być więcej. Nie sposób jednak zaliczyć wszystkich nieślubnych dzieci na poczet wojskowych, o czym przekonują dane z XIX wieku, kiedy rosła liczba ludności cywilnej i nieślubnych dzieci przy wyraźnym redukowaniu garnizonu.

33 AP KZ, ASG, sygn. 33: Die Beschwerden des Magistrats zu Silberberg über den Commandant Obr. Lieutenant v. Schlemmer wegen Jurisdictions Eingriffe [1800].

${ }^{34}$ AA Wr, sygn. 481f; 481a; 481b.

35 T. Przerwa, Zdrowotność garnizonu twierdzy srebrnogórskiej 1775-1815 [w:] Śląsk, Polska, Niemcy na przestrzeni wieków, red. T. Kulak, Torun 2008, s. 295-307. 
Najwartościowszymi nabywcami dóbr i usług byli oficerowie i urzędnicy garnizonowi, których odejście w 1860 roku mieszkańcy odczuli szczególnie boleśnie ${ }^{36}$. Zwykli żołnierze otrzymywali niski żołd, stąd - szczególnie po założeniu rodziny - musieli szukać dodatkowego zarobku. We fryderycjańskich koszarach często trudniono się przędzalnictwem. Podobnych praktyk możemy się domyślać również w przypadku Srebrnej Góry, za czym przemawiają tkackie tradycje miasteczka. Część praktykowała zapewne u srebrnogórskich majstrów lub jako robotnicy dniówkowi. Przynajmniej niektórzy mogli konkurować z cywilnymi rzemieślnikami, co zapewne generowało konflikty. Jeden z podróżnych odnotował, że żołnierze dorabiali zajęciami typowo mieszczańskimi ${ }^{37}$, ale nie wiemy, co kryło się za tą konstatacją. Sprawa Birnbaum dowodzi, że przedstawiciele stanu żołnierskiego wykazywali aktywność także w usługach. W miasteczku stacjonowały oddziały forteczne, dlatego w wojennych latach - inaczej niż w przypadku większych miast garnizonowych nie opuszczały one miejsca stałego pobytu. Miejscowy rynek nie był tym samym pozbawiany liczącej się grupy nabywców towarów czy usług oraz pracowników. Pozostając przy kwestiach gospodarczych, warto wspomnieć, że decyzja Fryderyka Wielkiego o budowie twierdzy mogła zablokować potencjalne odrodzenie podupadłego górnictwa rudnego, nie jest przy tym przesądzone, że do takowego w ogóle by doszło. W zamian można za to mówić o rozkwicie wapiennictwa w rejonie Przełęczy Srebrnej, gdzie powstały nowe wapienniki i uruchomiono forteczny łom wapienia ${ }^{38}$. $\mathrm{W}$ związku z potężną inwestycją powstały nadto cegielnia i tartak. Pozostanie w sferze domysłów, czy pracowały one wyłącznie na potrzeby twierdzy. Zauważmy na marginesie, że rozmach prac budowlanych robił na podróżnych spore wrażenie, podobnie musieli je postrzegać również mieszkańcy peryferyjnej Srebrnej Góry.

Wspominane wielokroć twierdza i garnizon zdominowały miasteczko (zarówno w pozytywnym, jak i negatywnym rozumieniu tego słowa), dając mu kilka dekad względnie spokojnego rozwoju. O ile pominiemy pojedyncze skargi na komendantów, z zachowanych źródeł wyłania się zasadniczo pozytywny obraz zachodzących zmian. O negatywnych konsekwencjach królewskiej decyzji zaczęto pisać dopiero po 1807 roku, kiedy miasto doznało ogromnych zniszczeń podczas szturmu wojsk napoleońskich (bawarskich) ${ }^{39}$. Ówczesny dramat mieszkańców pozbawionych domostw i dobytku przysłonił wcześniejsze korzyści. Warownia traciła zresztą pierwotny blask, a garnizon dawną wielkość, dlatego ich wpływ na rozwój miejscowości stawał się coraz słabszy. Jednoznacznie negatywny obraz dziejów miasteczka w epoce fryderycjańskiej pojawił się dopiero w polskich opracowaniach okresu powojennego. Zauważmy, że za formułowanymi podówczas ocenami nie stały rzetelne dociekania źródłowe. Tadeusz Broniewski pisał zatem o rzekomo rozpaczliwym położeniu srebr-

36 GStA PK, I HA, Rep. 77, tit. 1296, Nr. 4a: Die Demolierung der Festung 1860-1864.

37 J.W. Fischer, op. cit., s. 61.

38 T. Przerwa, Wapiennictwo ziemi ząbkowickiej [w:] Od regaliów po dobro narodowe. Ochrona i wykorzystanie zasobów środowiska naturalnego na ziemiach polskich - aspekt historyczny, red. T. Głowiński, M. Zawadka, Wrocław 2016, s. 189-190.

39 T. Przerwa, Nieszczęsne miasteczko: skutki oblężenia w $1807 \mathrm{r}$. [w:] Twierdza srebrnogórska, II: Wojna ..., s. 100-112. 
nogórzan w okresie budowy twierdzy. Mieszkańcy i żołnierze mieli według opisu tegoż autora żyć w izolacji, a ograniczenia przepływu ludności i wolności osobistej jakoby zahamowały rozwój gospodarczy miasteczka, tak iż wydrenowane daninami popadło ono w letarg ${ }^{40}$. Przywołana wizja mogła odpowiadać polskiemu odbiorcy, ale wykraczała poza granice dozwolonej interpretacji źródeł historycznych. Przypadek Srebrnej Góry powinien zachęcać do dalszych studiów nad funkcjonowaniem pruskich garnizonów na Śląsku i nad ich wpływem na życie lokalnych społeczności. Wyniki prac historyków niemieckich dotyczące innych miejscowości i regionów pokazują, jak bardzo potrzebne jest pogłębione i pozbawione emocji spojrzenie na epokę fryderycjańską właśnie przez taką soczewkę ${ }^{41}$. Przy okazji pojawiają się ważne pytania, w tym o socjalizacyjny wpływ armii na ludność miejską.

W przypadku Srebrnej Góry ograniczony zasób źródłowy nie pozwolił rozwinąć wielu wątków związanych z funkcjonowaniem garnizonu i obsługą zespołu fortecznego w okresie fryderycjańskim. Niemniej przedstawione fakty dały okazję do zadania podstawowego pytania o wpływ królewskiej inwestycji na życie dawnego miasteczka górniczego. Na skutek wojennych doświadczeń Fryderyk II postanowił zbudować górską warownię w pogranicznej okolicy w sąsiedztwie miejscowości pozbawionej fortyfikacji i niedostosowanej potencjałem do realizowanych planów. Warto podkreślić ten ostatni wątek, ponieważ stanowi on o wartości srebrnogórskiej soczewki. W omawianym okresie trudno wskazać na Śląsku miasto równie zdominowane przez wojsko. Podobnej wielkości ośrodków miejskich z pewnością nie brakowało, ale tylko w Srebrnej Górze zachodziła potrzeba wprowadzenia tak dużego garnizonu. Już choćby to oddaje wartość przyjętej perspektywy. Brak innego, równie wyraźnego czynnika rozwojowego pozwala zwrócić uwagę na niektóre problemy. Wydaje się, że budowa twierdzy i ustanowienie garnizonu doprowadziły do przynajmniej częściowej zmiany profilu gospodarczego miejscowości. Nie jest przy tym pewne, jak ten proces przebiegał i jakie czynniki nań wpływały. $Z$ pewnością nie można tu pominąć zapoczątkowanego pod koniec XVIII wieku kryzysu tkactwa, które było wcześniej głównym segmentem miejscowej produkcji i handlu. Obsługa wojska nie doprowadziła w każdym bądź razie do wyraźnego przyrostu ludności. Wzrost zaludnienia Srebrnej Góry wiązał się za to z przybyciem żołnierzy i ich rodzin. Nie udało się stwierdzić, w jakim stopniu wpływało to na życie miasta. W jego ograniczonej przestrzeni obie społeczności nawiązały jednak bliższe relacje, o czym świadczą zawierane małżeństwa i proszenie na świadków. Ogólnie lub jednostkowo poświadczona przebudowa/rozbudowa miejscowości stała się możliwa dzięki wzmocnieniu podstaw materialnych jej mieszkańców, istotnemu wzrostowi popytu na mieszkania, a zapewne również dzięki uruchomieniu fortecznych wapienników, cegielni i tartaku. Modernizacja objęła także infrastrukturę, o czym świadczą między innymi uruchomienie połączenia pocztowego, oświetlenie ulic latarniami czy

40 T. Broniewski, Srebrna Góra, Wrocław 1974, s. 9, 21.

${ }^{41}$ Zob. m.in. D. Schneider, Soldaten in der Stadt. Militär und Gesellschaft in Nauen 1763-1806, München 2003. 
otwarcie apteki. Garnizon przyniósł ze sobą różne, często odległe wzorce kulturowe, ale ich transfer pozostaje w zachowanych źródłach właściwie niewidoczny.

\section{BIBLIOGRAFIA}

\section{Źródła archiwalne}

Archiwum Archidiecezjalne we Wrocławiu

Księgi metrykalne parafii w Srebrnej Górze

sygn. 481a: Tauf-Buch der Kirche zu Silberberg 1766-1785.

sygn. 481b: Tauf-Buch der Kirche zu Silberberg 1785-1811.

sygn. 481f: Trauungs-Buch der Kirche zu der Catholischen Curatie Silberberg 17661817.

Archiwum Państwowe we Wrocławiu. Oddział w Kamieńcu Ząbkowickim

Akta miasta Srebrna Góra

sygn. 8: Einrichtung des Laternen Wesens zu Silberberg 1799-1807.

sygn. 31: Die über den Commandanten zu Silberberg Major de Haas beygebrachte Beschwerde wegen unterbrochener öffentlicher Passage durch die Stadt 1780.

sygn. 32: Die zu Silberberg zur Wohnung für den dortigen Kommandanten erkaufte Adolphschne Hauses 1794-1795.

sygn. 33: Die Beschwerden des Magistrats zu Silberberg über den Commandant Obr. Lieutenant v. Schlemmer wegen Jurisdictions Eingriffe [1800].

sygn. 65: Bericht des Syndikus der Stadt Silberberg über die dortige katholische Kapelle und summarisches Verzeichnis der evang. u. kathol. Einwohner.

Biblioteka Śląska w Katowicach. Oddział Zbiorów Specjalnych

sygn. R 1688 III/1: Besondere Nachricht der freyen Bergstadt Silberberg.

sygn. R 1688 III/2: C.G. Pohl, Chronick von Silberberg zur Fortsatzung der Geschichte von 1795 .

Geheimes Staatsarchiv, Stiftung Preußischer Kulturbesitz

I HA, Rep. 77, tit. 1296, Nr. 4a: Die Demolierung der Festung 1860-1864.

I HA, Rep. 77, tit. 1296, Nr. 5: Instandsetzung der Pallisades von Silberberg 1811-1812.

I HA, Rep. 89, Nr. 30446: Das Retablissement von Cosel und Silberberg 1813/19.

I HA, Rep. 151, Nr. 11575: Die Unterstützung für die durch die Belagerungen der schlesischen Festungen verunglückten Unterthanen bei Silberberg, Glatz, Cosel.

I HA, Rep. 151, Nr. 11582: Unterstützungen für die durch Belagerungen der schlesischen Festungen verunglückten Unterthamen bei Silberberg, Glatz, Cosel 1812. 


\section{Zbiory własne Autora}

Ernst G., Designation, Silberberg 1795 (kopia rękopisu).

Frisch M., Im Namen der Allerheiligsten und Hochgelobten Dreieinigkeit, Silberberg 1795 (kopia rękopisu).

\section{Prace i źródła drukowane}

Auszüge aus den Akten (Tagebuch) der Stadtverwaltung Silberberg im Eulengebirge 17901811, Hrsg. H. Felkel, U. Felkel, Hamburg 1999.

Bartscht A., Aus Silberbergs friedericianischer Epoche [w:] Festschrift der Hundertjahr-Feier zur Erinnerung an die standhafte Verteidigung Silberbergs, Silberberg 1907.

Bleyl W., Silberberg. Die Passfestung Schlesiens, Breslau 1938.

Brachmann W., Beiträge zur Apothekengeschichte Schlesiens, Würzburg 1966.

Broniewski T., Srebrna Góra, Wrocław 1974.

Dębicki J., Pod straża gór - pod straża twierdzy. Srebrna Góra u zbiegu epok: habsburskiej i fryderycjańskiej [w:] Twierdza srebrnogórska, II: Wojna 1806-1807-miasteczko, red. T. Przerwa, G. Podruczny, Wrocław 2008, s. 9-18.

Dębicki J., Srebrna Góra w czasie konfesjonalizacji [w:] Twierdza srebrnogórska, III: Miasteczko i fortyfikacje, red. T. Przerwa, G. Podruczny, Wrocław 2010, s. 20-32.

Fischer J.W., Bemerkungen auf einer Reise durch einen Theil des Schlesischen Gebirges und der Grafschaft Glaz, Breslau 1793.

Generalne tabele statystyczne Śląska 1787 roku, oprac. T. Ładogórski, Wrocław 1954.

Hasse E., Chronik der Stadt Reichenbach im Eulengebirge, Reichenbach 1929.

Pfeiffer E., Die Revuereisen Friedrichs des Grossen, Berlin 1904.

Podruczny G., Przerwa T., Twierdza Srebrna Góra, Warszawa 2010.

Przerwa T., Nieszczęsne miasteczko: skutki oblężenia w 1807 r. [w:] Twierdza srebrnogórska, II: Wojna 1806-1807-miasteczko, red. T. Przerwa, G. Podruczny, Wrocław 2008, s. $100-112$.

Przerwa T., Twierdza srebrnogórska oczami podróżników (1763-1867) [w:] Twierdza srebrnogórska, red. T. Przerwa, G. Podruczny, Srebrna Góra 2006, s. 87-98.

Przerwa T., Wapiennictwo ziemi ząbkowickiej [w:] Od regaliów po dobro narodowe. Ochrona i wykorzystanie zasobów środowiska naturalnego na ziemiach polskich - aspekt historyczny, red. T. Głowiński, M. Zawadka, Wrocław 2016, s. 185-193.

Przerwa T., Zdrowotność garnizonu twierdzy srebrnogórskiej 1775-1815 [w:] Ślask, Polska, Niemcy na przestrzeni wieków, red. T. Kulak, Toruń 2008, s. 295-307.

Przerwa T., Życie w cieniu fryderycjańskiej twierdzy: przypadek Srebrnej Góry [w:] Zamki, twierdze i garnizony Opola, Śląska i dawnej Rzeczypospolitej, red. T. Ciesielski, Zabrze 2010, s. 97-108.

Rödenbeck K.H.S., Tagebuch oder Geschichtskalender aus Friedrich's des Großen Regentenleben (1740-1786), Bd. 2, Berlin 1841; Bd. 3, Berlin 1842.

„Schlesische Provinzialblätter”, Bd. XIX (1794) - Bd. XLIV (1806).

Schneider D., Soldaten in der Stadt. Militär und Gesellschaft in Nauen 1763-1806, München 2003.

Schummel J.G., Reise durch Schlesien im Julius und August 1791, Breslau 1792. 
Weigel J.A.V., Geographische, naturhistorische und technologische Beschreibung des souverainen Herzogthums Schlesien, T1. 3, Berlin 1801.

Weiss Ch., Wanderungen in Sachsen Schlesien Glatz und Böhmen, Tl. 2, Leipzig 1797.

Zimmermann F.A., Beyträge zur Beschreibung von Schlesien, Bd. I, Stück 4, Brieg 1783, s. 64. 